OPEN ACCESS

Edited by:

Eric Von Wettberg,

University of Vermont, United States

Reviewed by:

Paul Kiprotich Kimurto,

Egerton University, Kenya

Sivakumar Sukumaran,

International Maize and Wheat

Improvement Center, Mexico

Petr Smýkal,

Palacký University, Olomouc, Czechia

*Correspondence:

Shivali Sharma

shivali.sharma@cgiar.org

Specialty section:

This article was submitted to

Plant Breeding,

a section of the journal

Frontiers in Plant Science

Received: 09 January 2020

Accepted: 26 June 2020

Published: 23 July 2020

Citation:

Sharma S, Paul PJ, Sameer Kumar CV and Nimje $C$ (2020) Utilizing Wild Cajanus platycarpus, a Tertiary Genepool Species for Enriching Variability in the Primary Genepool for Pigeonpea Improvement.

Front. Plant Sci. 11:1055. doi: 10.3389/fp/s.2020.01055

\section{Utilizing Wild Cajanus platycarpus, a Tertiary Genepool Species for Enriching Variability in the Primary Genepool for Pigeonpea Improvement}

\author{
Shivali Sharma ${ }^{1 *}$, Pronob J. Paul ${ }^{1}$, CV Sameer Kumar ${ }^{2}$ and Chetna Nimje ${ }^{3}$ \\ 1 Theme Pre-breeding, International Crops Research Institute for the Semi-Arid Tropics (ICRISAT), Hyderabad, India, \\ ${ }^{2}$ Regional Agricultural Research Station, Professor Jayashanker Telangana State Agricultural University, Palem, India, \\ ${ }^{3}$ Grain Quality Lab., International Crops Research Institute for the Semi-Arid Tropics (ICRISAT), Hyderabad, India
}

The use of crop wild relatives in the breeding program has been well recognized to diversify the genetic base along with introgression of useful traits. Cajanus platycarpus (Benth.) Maesen, an annual wild relative belonging to the tertiary genepool of pigeonpea, possesses many useful traits such as early maturity, high protein content, photoperiod insensitivity, and pod borer tolerance for the genetic improvement of cultivated pigeonpea. Using this cross incompatible wild Cajanus species, an advanced backcross population was developed following the embryo rescue technique. In the present study, a prebreeding population consisting of 136 introgression lines (ILs) along with five popular varieties (used as checks) was evaluated for important agronomic traits during 2016 and 2017 rainy seasons and for grain nutrient content during 2016, 2017, and 2018 rainy seasons. Large genetic variation was observed for agronomic traits such as days to $50 \%$ flowering, number of pods per plant, pod weight per plant, grain yield per plant, and grain nutrients [protein content, grain iron (Fe), zinc (Zn), calcium (Ca), and magnesium (Mg)] in the pre-breeding population. Significant genotype $\times$ environment interaction was also observed for agronomic traits as well as grain nutrients indicating the sensitivity of these traits to the environments. No significant correlations were observed between grain yield and grain nutrients except grain Zn content which was negatively correlated with grain yield. Overall, 28 promising high-yielding ILs with high grain nutrient content were identified. These ILs, in particular, ICPP \# 171012, 171004, 171102, 171087, 171006, and 171050 flowered significantly earlier than the popular mega variety, ICPL 87119 (Asha) and thus hold potential in developing new short-duration cultivars. The comprehensive multi-site assessment of these high-yielding, nutrient-rich accessions would be useful in identifying region-specific promising lines for direct release as 
cultivars. Moreover, these ILs are expected to replace the popular existing cultivars or for use as new and diverse sources of variations in hybridization programs for pigeonpea improvement.

Keywords: Cajanus platycarpus, pre-breeding, introgression lines, wild Cajanus species, pigeonpea, grain nutrients, short-duration, photo-insensitivity

\section{INTRODUCTION}

Pigeonpea [Cajajus cajan (L.) Milllspaugh] is an important often-cross pollinated grain legume crop of semi-arid tropics grown under subsistence agriculture. Globally, it is cultivated on a $7.02 \mathrm{~m}$ ha area with an annual production of $6.81 \mathrm{~m} \mathrm{t}$ (FAOSTAT, 2017) mainly in Asia, Africa, and Latin America. India is the largest producer and consumer of pigeonpea in the world where dry, dehulled split seeds are consumed as "daal", a source of protein-rich (22-24\%) food. Besides protein, pigeonpea seeds are also rich in carbohydrates, minerals, crude fibre, iron $(\mathrm{Fe})$, sulphur, calcium $(\mathrm{Ca})$, potassium $(\mathrm{K})$, manganese $(\mathrm{Mn})$ and water-soluble vitamins especially thiamine, riboflavin, and niacin (Saxena et al., 2010). In India, pigeonpea is the second most important legume after chickpea accounting for $5.39 \mathrm{~m}$ ha area and $4.87 \mathrm{~m} \mathrm{t}$ of production (FAOSTAT, 2017). Besides mature seeds, immature green tender pods and seeds are consumed as vegetables mainly in Kenya, Tanzania, and Malawi. The crop is also grown for other uses such as fodder, medicine, rearing lac producing insects, fuelwood, and improving soil fertility through biological nitrogen fixation.

Narrow genetic base of cultivated pigeonpea and repeated use of a few elite breeding lines such as T-1 and T-90 (Kumar et al., 2004) in breeding programs are the major factors hindering its genetic improvement. Further, various biotic and abiotic stresses cause huge yield losses in pigeonpea worldwide and high levels of resistance/tolerance are not available in cultivated genepool. As a result, despite large breeding efforts in India and elsewhere, pigeonpea productivity is stagnant around 0.8-0.9 $\mathrm{t} \mathrm{ha}^{-1}$. Major biotic stresses affecting pigeonpea are pod borers (Helicoverpa armigera Hubner, Maruca vitrata Geyer), and pod fly (Melanagromyza chalcosoma Spencer) among insect-pests and fusarium wilt (Fusarium udum Butler), sterility mosaic disease (SMD), and phytophthora blight (Phytophthora drechsleri Tucker) among diseases. Pigeonpea crop is also sensitive to abiotic stresses such as terminal drought, water-logging, salinity, and frost/cold. The protein advisory group of the United Nations has emphasized on improvement of the nutritional quality of proteins besides improving the productivity, adaptability, and yield stability of grain legumes.

One of the key factors for a successful crop improvement program is the availability of sufficient genetic variability. Over 13,200 accessions of cultivated pigeonpea and 555 accessions of wild species belonging to genus Cajanus from 60 countries are conserved in ICRISAT genebank. These germplasm accessions, based on the crossability relationship with cultivated pigeonpea, are grouped into three genepools with cultivated germplasm in the primary genepool (GP 1), all cross-compatible species,
C. acutifolius (F.Muell.) Maesen, C. albicans (Wight \& Arn.) Maesen, C. cajanifolius (Haines) Maesen, C. cinereus (F.Muell.), C. confertiflorus F. Muell., C. lanceolatus (W.Fitzg.) Maesen, C. latisepalus Maesen, C. lineatus (Wight \& Arn.) Maesen, C. reticulatus (Dryand.) F.Muell., C. scarabaeoides (L.) Thouars, C. sericeus (Baker) Maesen, C. trinervius (DC.) Maesen in the secondary genepool (GP 2), and the cross-incompatible species, C. crassus (King) Maesen, C. goensis Dalzell, C. mollis (Benth.) Maesen, C. platycarpus (Benth.) Maesen, C. rugosus (Wight \& Arn.) Maesen, C. heynei, C. kerstingii, C. volubilis, and other Cajaninae such as Rhynchosia Lour., Dunbaria W. and A., Eriosema (DC.) Reichenb in the tertiary genepool (GP 3). Wild Cajanus species are the reservoirs of many useful genes/alleles and can be used to enrich variability in the primary genepool for developing new broad-based cultivars with increased plasticity (Sharma et al., 1993; Rao et al., 2003; Sharma and Upadhyaya, 2016; Sharma et al., 2019). Introgression of useful genes/alleles from the wild Cajanus species would help to break the yield plateau in pigeonpea. In chickpea, interspecific derivatives having high yield and resistance for wilt, foot rot, and root rot diseases (Singh et al., 2005) as well as for cyst nematode (Malhotra et al., 2002) were developed from crosses involving C. reticulatum. Similarly high-yielding, cold-tolerant lines with high biomass (ICARDA, 1995) and resistance to phytophthora root rot were developed from interspecific crosses involving $C$. echinospermum (Knights et al., 2008). Frequent utilization of wild Cajanus species in breeding programs is hindered due to cross incompatibility barriers and linkage drag. Among wild species, C. platycarpus is of particular interest to the pigeonpea breeders due to several useful traits such as extra-early flowering and maturity (Saxena et al., 1996), photoperiod insensitivity, prolific flowering and podding, high harvest index, annuality and rapid seedling growth, and resistance/tolerance to biotic and abiotic stresses such as pod borer (Sujana et al., 2008), Fusarium wilt (Saxena et al., 1990), phytophthora blight (Ariyanayagam and Spence, 1978; Pundir and Singh, 1987; Dundas, 1990), nematodes (Sharma, 1995), sterility mosaic (Lava Kumar et al., 2005) and salinity (Subbarao, 1988). Using this cross incompatible wild Cajanus species, C. platycarpus, a backcross population was developed following embryo rescue technique (Mallikarjuna et al., 2011).

Linkage drag is the most common problem associated with the utilization of wild species in breeding programs. Hence, utilization of wild species in creating new genetic variability will be successful only when introgression lines (ILs) with useful traits and acceptable agronomic performance are developed and made available to breeders for direct use in breeding programs. Therefore, the present investigation was carried out a) to study 
the genetic variability in the advanced backcross population derived from $C$. platycarpus for important agronomic traits and grain nutrient, and b) to identify stable promising traitspecific ILs with minimum linkage drag for ready use in breeding programs to develop new cultivars with a broad genetic base.

\section{MATERIALS AND METHODS}

\section{Plant Material and Field Evaluation}

Using a cross incompatible wild Cajanus species, C. platycarpus accession ICPW 68, and a popular pigeonpea cultivar ICPL 85010, a backcross population was developed following embryo rescue technique (Mallikarjuna et al., 2006). ICPW 68, originated from Uttar Pradesh, India, is extra-early flowering accession having high seed protein content (Saxena et al., 1996) and pod borer resistance (Sujana et al., 2008). ICPL 85010, also known as "Sarita", is a short duration, determinate type pigeonpea variety having medium seed size (9.5 g 100-seed weight), which is cultivated in the Indian Subcontinent (Dahiya et al., 2001). Embryo rescue and tissue culture techniques were followed as described by Mallikarjuna and Moss (1995). The details of the population development have been documented by Mallikarjuna et al. (2006). The advanced backcross population consisting of 136 ILs in $\mathrm{BC}_{4} \mathrm{~F}_{10}$ generation was used in this study. The 136 ILs along with five popular varieties (used as checks) of different maturity durations [ICPL 87119 (also known as "Asha") ICP 8863 (Maruti), ICPL 20325, ICPL 85010, and ICPL 88039] were evaluated for different agronomic traits during the 2016 and 2017 rainy seasons and grain nutrients during the 2016, 2017, and 2018 rainy seasons at ICRISAT, Patancheru, Telangana, India $\left(17^{\circ} 51^{\prime} \mathrm{N}, 78^{\circ} 27^{\prime} \mathrm{E} ; 545 \mathrm{~m}\right)$. Among the checks, ICPL 87119 is a popular mega variety in the medium maturity duration group that is being widely cultivated in India over the past two decades; ICP 8863 is a medium-duration, high-yielding pigeonpea variety resistant to fusarium wilt which is popular in Karnataka, India; ICPL 20235 and ICPL 88039 are super-early and early maturing pigeonpea varieties, respectively. Accessions were planted in black soil (Vertisols) precision field in the first week of July in all years in an augmented design. Each check was placed after every 10 entries in each block and total lines were divided into three blocks. Each accession was sown in a single $4 \mathrm{~m}$ long row in a ridge and furrow system with a plant-to-plant spacing of $20 \mathrm{~cm}$ and row to row spacing of $75 \mathrm{~cm}$. A standard package of practices was followed to raise a healthy crop. Manual weeding and spraying of insecticide were done to control weeds and insectpests damage. The weather data of 2016 and 2017 crop season at ICRISAT, Patancheru, India is given in Supplementary Figure 1. Data were recorded on eight agronomic traits [days to first flowering, days to $50 \%$ flowering, plant height $(\mathrm{cm})$, number of primary branches, number of secondary branches, number of pods per plant, pod weight per plant (g), and grain yield per plant (g)], and five grain nutrients [protein content (\%), iron (Fe in $\mathrm{mg} \mathrm{kg}^{-1}$ ), zinc ( $\mathrm{Zn} \mathrm{in} \mathrm{mg} \mathrm{kg}^{-1}$ ), calcium (Ca in $\mathrm{g} \mathrm{kg}^{-1}$ ), and magnesium ( $\mathrm{Mg}$ in $\mathrm{g} \mathrm{Kg}^{-1}$ ) content]. Data on grain nutrients and two agronomic traits namely days to first flowering, and days to $50 \%$ flowering were recorded on a plot basis, whereas data on remaining agronomic traits (plant height, primary branches per plant, secondary branches per plant, pods per plant, pod weight per plant and grain yield per plant) were recorded on five randomly selected representative plants per plot following pigeonpea descriptors (IBPGR and ICRISAT, 1993). All the lines were harvested and threshed manually.

\section{Estimation of Grain Nutrient Content}

For estimating the nutrient contents of $\mathrm{Fe}, \mathrm{Zn}, \mathrm{Mg}, \mathrm{Ca}$, and protein in grains, seeds of 136 ILs along with five checks were cleaned thoroughly and special care was taken during cleaning to prevent contamination of seeds with dust and metal particles. Seeds were washed with distilled water for a few seconds and dried in hot air at $40^{\circ} \mathrm{C}$ for $2 \mathrm{~h}$ to remove the dust and metal particles. Well-cleaned random seed samples were used for estimating grain protein, $\mathrm{Fe}, \mathrm{Zn}, \mathrm{Ca}$, and $\mathrm{Mg}$ contents at the Charles Renard Analytical Laboratory, ICRISAT, Patancheru, India. The four dietary minerals- $\mathrm{Fe}, \mathrm{Zn}, \mathrm{Ca}$, and $\mathrm{Mg}$ contents were assessed by nitric acid and hydrogen peroxide digestion accompanied by inductively coupled plasma optical emission spectrometry (ICP-OES) (Wheal et al., 2011). The sulfuric acidselenium digestion method was adopted for the estimation of grain protein followed by the estimation of total nitrogen $(N)$ in a SKALAR SAN $^{++}$SYSTEM autoanalyzer and the measurement of protein percentage as $\mathrm{N}$ percent $\times 6.25$ conversion factor (Sahrawat et al., 2002).

\section{Statistical Analysis}

Eight agronomic traits and five grain nutrients were analyzed separately for each rainy season and pooled over the two seasons for agronomic traits, and three seasons for grain nutrients using residual maximum likelihood (REML) in GenStat 15 (https:// www.vsni.co.uk/) in mixed model approach considering genotypes as random effect and environment as fixed effect. The significance of environments was tested using Wald's statistic. Variance components due to genotype $\left(\sigma_{g}^{2}\right)$ and genotype $\times$ environment $\left(\sigma_{g \times e}^{2}\right)$ interaction and their standard errors (SE) were estimated. Best linear unbiased predictors (BLUPs) were obtained for agronomic traits and grain nutrients for each accession for individual environment as well as pooled over the environments. Based on BLUPs, the range, mean, variances and broad-sense heritability $\left(\mathrm{H}^{2}\right)$ were estimated. Phenotypic correlations were estimated to determine trait associations in GenStat 15. Path analysis was performed to estimate the direct effect of the traits towards grain yield using $\mathrm{R}$ Version 3.5.3 (R Project for Statistical Computing, http://www.rproject.org/). To avoid the multicollinearity issues, two independent traits, days to 50\% flowering and pod weight per plant were excluded while performing path analysis. Using the $\mathrm{R}$ package cluster (Patterson and Thompson, 1971), the Euclidean dissimilarity matrix was constructed using agronomic traits and grain nutrients and the accessions were clustered following Ward's method. Further, accessions with high grain yield and high grain $\mathrm{Fe}, \mathrm{Zn}, \mathrm{Ca}, \mathrm{Mg}$, and protein content were identified. Using the Euclidian distance matrix, the most diverse accession 
pairs were identified for potential use as parents in pigeonpea crossing programs.

\section{RESULTS}

\section{Variance Components and Trait Variability}

The REML analysis showed significant variations among ILs $\left(\sigma_{g}^{2}\right)$ for all the eight agronomic traits in both 2016 and 2017 rainy seasons and all the five grain nutrients in 2016, 2017 and 2018 rainy seasons indicating the presence of significant variability among the ILs for these traits. Pooled analysis also showed significant genetic variance $\left(\sigma_{g}^{2}\right)$ and significant $\mathrm{G} \times \mathrm{E}$ interactions for all agronomic traits and grain nutrients (Table 1).

A large variation was observed amongst the ILs for all the agronomic traits and grain nutrients in each season as well as in the pooled analysis (Table 2). It is evident that some of the ILs performed better than the popular variety ICPL 87119 and the recurrent parent ICPL 85010 for these traits. A flowering window of around 60 days (76-141 days range) was observed for days to $50 \%$ flowering showing substantial population variability while popular variety ICPL 87119 took $~ 123$ days to $50 \%$ flowering. None of the ILs flowered earlier than the recurrent parent ICPL 85010 (67 days to 50\% flowering). Large variation was also noted amongst the ILs for plant height (above $100 \mathrm{~cm}: \sim 128-272 \mathrm{~cm}$ ) when compared with the popular variety ICPL 87119 (on an average $222 \mathrm{~cm}$ tall) (Table 2). Similarly, number of pods per plant were much higher in the ILs (up to 386 pods in 2016 and 303 pods per plant in 2017) compared to ICPL 87119 (average 171 pods per plant) and the cultivated parent ICPL 85010 (average 126 pods per plant) in both seasons. Similar pattern was observed in 2016, 2017, and in pooled analysis for other traits such as grain yield per plant (up to $83 \mathrm{~g}$ in ILs compared to $48 \mathrm{~g}$ in ICPL 87119 and $25 \mathrm{~g}$ in ICPL 85010), protein content (up to $23 \%$ in ILs compared to $19 \%$ in ICPL 87119 and $21 \%$ in ICPL 85010), Fe (up to $43 \mathrm{mg} \mathrm{kg}^{-1}$ in ILs compared to $32 \mathrm{mg} \mathrm{kg}^{-1}$ in ICPL 87119 and $33 \mathrm{mg} \mathrm{kg}^{-1}$ in ICPL 85010), Zn (up to $42 \mathrm{mg} \mathrm{kg}^{-1}$ in ILs compared to $29 \mathrm{mg} \mathrm{kg}^{-1}$ in ICPL 87119 and $41 \mathrm{mg} \mathrm{kg}^{-1}$ in ICPL 85010), Ca (up to $3.1 \mathrm{~g} \mathrm{~kg}^{-1}$ in ILs compared to $\sim 1.0 \mathrm{~g} \mathrm{~kg}^{-1}$ both in ICPL 87119 and ICPL 85010), and $\mathrm{Mg}$ (up to $1.6 \mathrm{~g} \mathrm{~kg}^{-1}$ in ILs compared to $\sim 1.3 \mathrm{~g} \mathrm{~kg}^{-1}$ in ICPL 87119 , and $1.1 \mathrm{~g} \mathrm{~kg}^{-1}$ in ICPL 85010) (Table 2).

\section{Associations Between Agronomic Traits and Grain Nutrients}

The correlation analysis in 2016 (Table S1), 2017 (Table S1), and pooled analysis over years (Figure 1) showed that grain yield per plant was significantly and positively associated with days to first flowering ( $\mathrm{r}=0.38$ in 2016, 0.42 in 2017 and 0.49 in pooled), days to $50 \%$ flowering ( $\mathrm{r}=0.40$ in 2016, 0.39 in 2017 and 0.48 in pooled), plant height ( $\mathrm{r}=0.24$ in 2016, 0.42 in 2017 and 0.37 in pooled), number of secondary branches $(r=0.50$ in 2016, 0.24 in 2017 and 0.42 in pooled), pods per plant $(r=0.92$ in 2016, 0.84 in 2017 and 0.90 in pooled), and pod weight per plant ( $r=0.99$ in 2016, 0.95 in 2017 and 0.98 in pooled) (Table S1, Figure 1). Number of primary branches had significantly positive correlation with grain yield per plant in $2017(\mathrm{r}=0.45)$ and pooled over years $(\mathrm{r}=0.25)$ but no correlation was observed in 2016 rainy season.

Similarly, among the grain nutrients, protein content in seeds showed significantly positive association with three nutrients, $\mathrm{Fe}$ ( $\mathrm{r}=0.23$ in 2016, 0.32 in 2017, 0.34 in pooled), $\mathrm{Zn}(\mathrm{r}=0.44$ in 2016, 0.32 in 2017, 0.40 in pooled), and $\mathrm{Mg}(\mathrm{r}=0.19$ in 2016, 0.21 in $2017,0.19$ in pooled). Significantly positive correlation was observed between Fe and $\mathrm{Zn}$ content ( $\mathrm{r}=0.37$ in 2016, 0.27 in 2017 and 0.37 in pooled) and between $\mathrm{Ca}$ and $\mathrm{Mg}$ content $(\mathrm{r}=$ 0.64 in 2016, 0.60 in 2017 and 0.67 in pooled) in year-wise and pooled analysis.

In the present study, no significant correlation was found between grain yield per plant with grain nutrients (Grain protein, $\mathrm{Ca}, \mathrm{Fe}$ ) in 2016 (Table S1), 2017 (Table S1), and pooled over years (Figure 1). Grain yield per plant showed a significantly negative correlation $(r=-0.28$ in $2016,-0.42$ in 2017 , and -0.43 in pooled) with Zn content. Further, the path analysis in 2016 (Table S2), 2017 (Table S2), and pooled analysis over the years

TABLE 1 | Variance components due to genotypes $\left(\sigma_{g}^{2}\right)$, genotype $\times$ environment $\left(\sigma_{g \times e}^{2}\right)$ interactions and their standard errors (SE) for agronomic traits and grain nutrients of C. platycarpus derived introgression lines evaluated during 2016, 2017, and 2018 rainy seasons at ICRISAT, Patancheru.

\begin{tabular}{|c|c|c|c|c|c|c|c|c|c|c|}
\hline \multirow[t]{2}{*}{ Traits } & \multicolumn{2}{|c|}{2016 rainy season } & \multicolumn{2}{|c|}{2017 rainy season } & \multicolumn{2}{|c|}{2018 rainy season } & \multicolumn{4}{|c|}{ Pooled over seasons } \\
\hline & $\sigma_{g}^{2}$ & SE & $\sigma_{g}^{2}$ & SE & $\sigma_{g}^{2}$ & SE & $\sigma_{g}^{2}$ & SE & $\sigma_{g \times e}^{2}$ & SE \\
\hline Days to first flowering & $146.61^{\star \star}$ & 19.460 & $228.28^{\star \star}$ & 28.030 & - & - & $143.51^{\star \star}$ & 20.388 & $41.51^{\star \star}$ & 6.634 \\
\hline Days to $50 \%$ flowering & $166.66^{\star \star}$ & 21.150 & $210.85^{\star \star}$ & 26.698 & - & - & $146.23^{\star \star}$ & 20.620 & $38.42^{\star \star}$ & 6.680 \\
\hline Plant height (cm) & $353.05^{\star \star}$ & 44.970 & $406.56^{\star \star}$ & 51.870 & - & - & $340.57^{\star *}$ & 44.170 & $36.98^{\star \star}$ & 8.860 \\
\hline Primary branches (no.) & $21.67^{\star \star}$ & 4.536 & $15.81^{\star \star}$ & 3.072 & - & - & $8.37^{\star \star}$ & 2.138 & $9.42^{* \star}$ & 2.649 \\
\hline Secondary branches (no.) & $21.65^{\star \star}$ & 3.290 & $8.728^{\star}$ & 3.443 & - & - & $6.97^{\star \star}$ & 1.779 & $7.14^{\star \star}$ & 2.354 \\
\hline Pods per plant (no.) & $5777.00^{\star *}$ & 1054.000 & $1909.30^{\star \star}$ & 353.200 & - & - & $2499.10^{\star \star}$ & 448.900 & $1282.70^{\star \star}$ & 380.600 \\
\hline Pod weight per plant (g) & $1005.20^{\star \star}$ & 147.200 & $259.43^{\star \star}$ & 47.100 & - & - & $322.70^{\star \star}$ & 66.240 & $306.23^{\star \star}$ & 53.780 \\
\hline Grain yield per plant (g) & $434.12^{\star \star}$ & 70.420 & $115.31^{\star *}$ & 20.540 & - & - & $150.59^{\star *}$ & 29.960 & $123.10^{\star \star}$ & 25.090 \\
\hline Protein (\%) & $1.52^{\star \star}$ & 0.281 & $1.53^{\star \star}$ & 0.244 & $1.25^{\star \star}$ & 0.361 & $0.43^{\star \star}$ & 0.115 & $1.05^{\star \star}$ & 0.150 \\
\hline $\mathrm{Fe}\left(\mathrm{mg} \mathrm{kg}^{-1}\right)$ & $19.11^{\star \star}$ & 2.813 & $11.39^{\star \star}$ & 2.669 & $20.77^{\star \star}$ & 2.730 & $8.91^{\star \star}$ & 1.536 & $8.73^{\star \star}$ & 1.099 \\
\hline $\mathrm{Zn}\left(\mathrm{mg} \mathrm{kg}{ }^{-1}\right)$ & $11.04^{\star \star}$ & 1.841 & $11.53^{\star \star}$ & 3.170 & $10.77^{\star \star}$ & 2.051 & $7.84^{\star \star}$ & 1.218 & $2.77^{\star \star}$ & 1.080 \\
\hline $\mathrm{Ca}\left(\mathrm{g} \mathrm{kg}^{-1}\right)$ & $0.16^{\star \star}$ & 0.024 & $0.18^{\star \star}$ & 0.026 & $0.21^{\star \star}$ & 0.027 & $0.13^{\star \star}$ & 0.018 & $0.05^{\star \star}$ & 0.008 \\
\hline $\operatorname{Mg}\left(g_{~ k g}-1\right)$ & $0.01^{\star \star}$ & 0.005 & $0.02^{\star \star}$ & 0.003 & $0.02^{\star \star}$ & 0.004 & $0.01^{\star \star}$ & 0.002 & $0.004^{*}$ & 0.002 \\
\hline
\end{tabular}

*Significant at $P \leq 0.05 ;{ }^{* *}$ Significant at $P \leq 0.01$. 


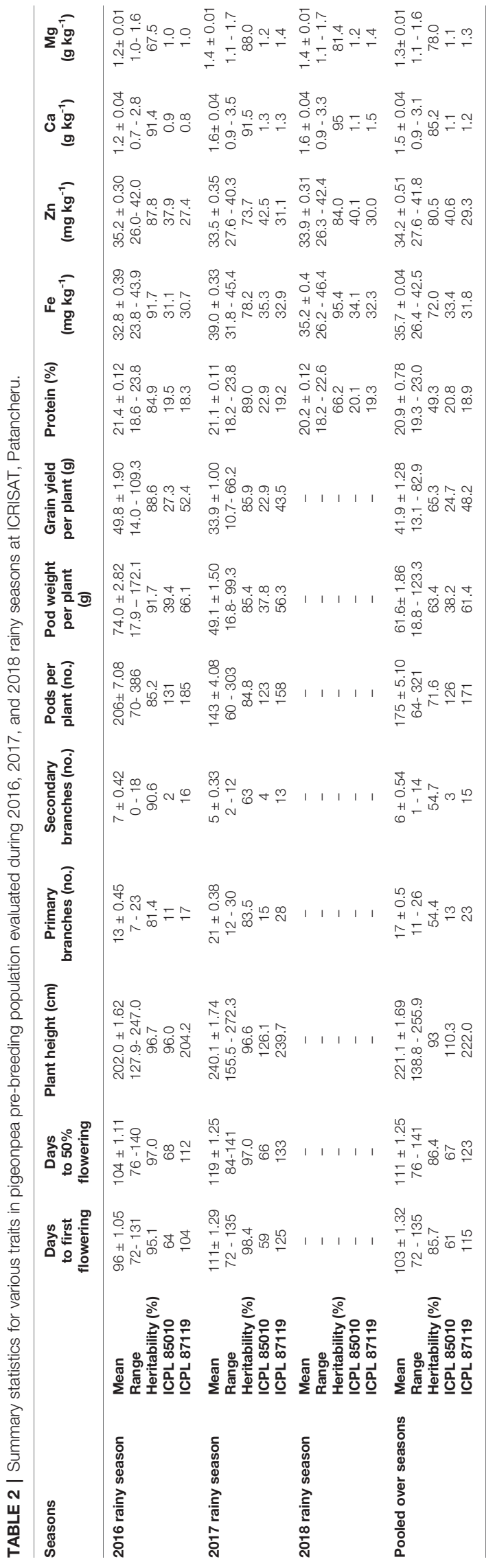

revealed that pods per plant is the major direct contributor to grain yield ( 0.872 in 2016, 0.765 in 2017, and 0.813 in pooled). The other two traits which showed a major contribution towards yield were number of secondary branches per plant and plant height (Table S2).

\section{Identification of Promising Introgression Lines (ILs)}

To understand the potential of these ILs derived from wild species in improving cultivated pigeonpea, the average performance of these lines over two years was compared with the popular variety, ICPL 87119 and the recurrent parent, ICPL 85010. None of the ILs flowered earlier than ICPL 85010 (days to $50 \%$ flowering $<70$ days). However, 104 ILs flowered significantly earlier (days to 50\% flowering: 81-119 days) than ICPL 87119 (123 days). The majority of the ILs (> 100 lines out of 136 lines) were found significantly better than recurrent parent ICPL 85010 for most of the agronomic traits such as pods per plant, pod weight per plant and grain yield per plant (Table 3). In comparison with ICPL 87119 ( $\sim 8$ g), 28 ILs ( 20\% of the backcross population) had significantly higher grain yield per plant ( 52-83 g) (Table 3). Besides, many ILs were found significantly better than ICPL 87119 in terms of plant height (50 ILs with $139-218 \mathrm{~cm}$ height), number of pods per plant (53 ILs with 189-321 pods) and pod weight per plant (55 ILs with 67-123 g). A few ILs also had a higher number of primary branches compared to ICPL 87119 (Table 3).

For grain nutrients, all the 136 ILs were found to have higher protein content $(\sim 19-23 \%)$ than the popular variety ICPL 87119 whereas, 104 ILs $\left(\sim 34-42 \mathrm{mg} \mathrm{kg}^{-1)}\right.$ in grain Fe content, $102 \mathrm{ILs}$ $\left(\sim 32-42 \mathrm{mg} \mathrm{kg}^{-1}\right)$ in grain Zn content, 74 ILs (1.35-3.09 $\left.\mathrm{g} \mathrm{kg}^{-1}\right)$ in grain Ca content, and 45 ILs $\left(1.35-1.59 \mathrm{~g} \mathrm{~kg}^{-1}\right)$ in grain $\mathrm{Mg}$ content were found significantly found better than ICPL 87119 (Table 3). Above 50 ILs were found promising than ICPL 85010 for most of the grain nutrient contents except $\mathrm{Zn}$ content (Table 3). Top five trait-specific ILs for each agronomic trait and grain nutrients are given in Table 3.

A total of 28 promising high-yielding ILs, which performed better than the popular variety, ICPL 87119 , were identified (Table 4). Most of these high-yielding ILs exhibited higher amounts of five grain-nutrient contents. Remarkably, one line ICPP 171012 was found early (50\% flowering: 109 days) having a high number of pods per plant (301), pod weight per plant (108 g), grain yield per plant $(73 \mathrm{~g})$, along with better grain nutrient contents such as high protein $(21 \%)$, grain $\mathrm{Fe}\left(35 \mathrm{mg} \mathrm{kg}^{-1}\right)$, grain $\mathrm{Zn}(36.16$ $\left.\mathrm{mg} \mathrm{kg}{ }^{-1}\right)$, grain $\mathrm{Ca}\left(1.39 \mathrm{~g} \mathrm{~kg}^{-1}\right)$, and grain $\mathrm{Mg}\left(1.30 \mathrm{~g} \mathrm{~kg}^{-1}\right)$ content compared to the best check ICPL 87119. Similarly, ILs ICPP \# 171004, 171102, 171087, 171006, and 171050 were found most promising in terms of early flowering (109-116 days), high yielding $(\sim 62-65 \mathrm{~g})$ and other agronomic traits along with higher grain nutrient contents than ICPL 87119 (Table 4).

\section{Cluster Analysis}

Cluster analysis is performed to categorize lines into distinct groups/ clusters wherein genotypes in different clusters are more diverse than within a cluster (Ward, 1963) and is useful in selecting the most diverse genotypes to be used as parents in crossing programs. 


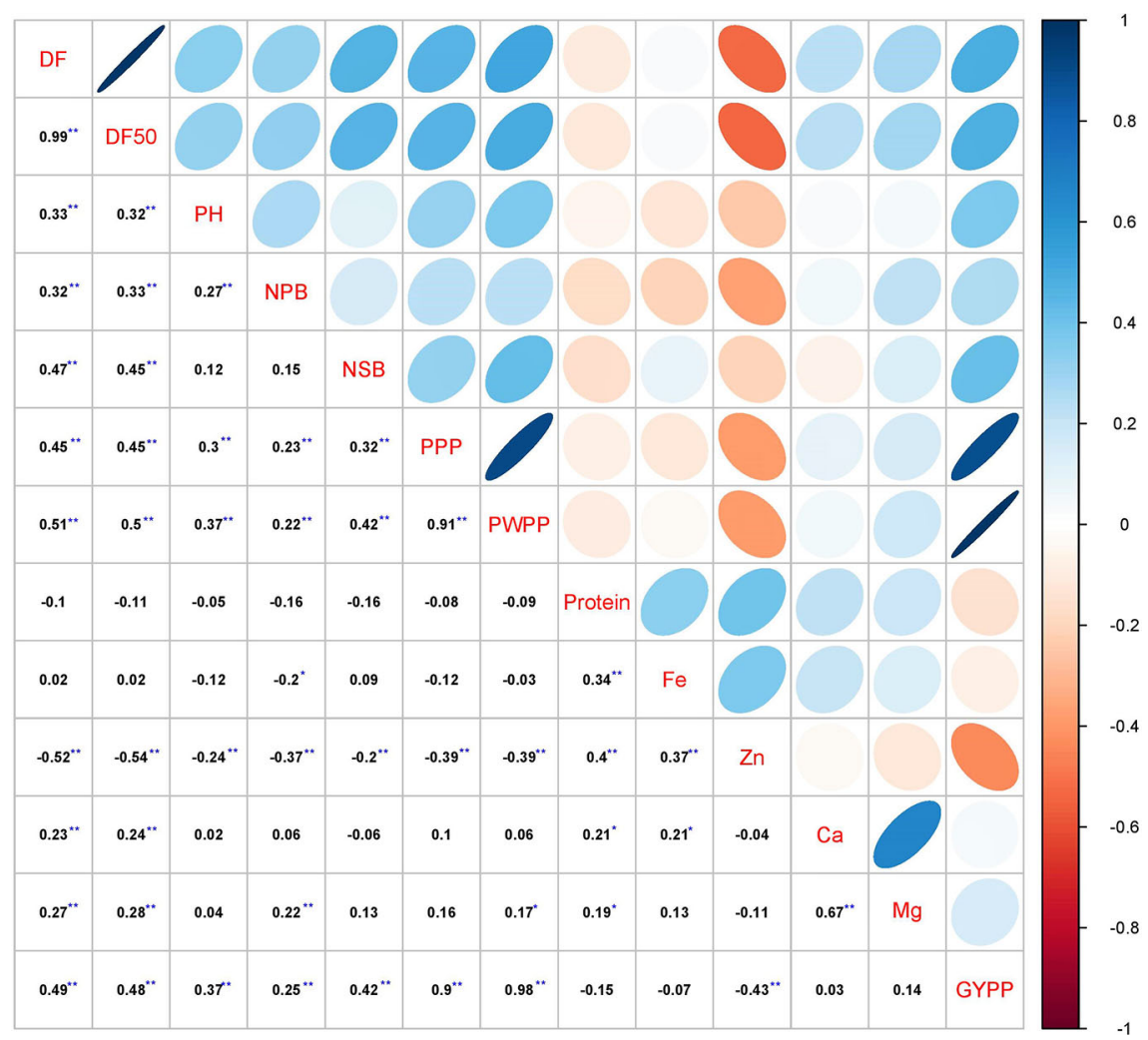

FIGURE 1 | Correlation analysis of various agronomic and grain nutrient traits in pigeonpea pre-breeding population derived from C. platycarpus at ICRISAT, Patancheru. Days to flowering (DF \& DF50), plant height (PH), primary branches (NPB), secondary branches (NSB), pods per plant (PPP), and pod weight per plant (PWPP) were positively associated with grain yield per plant (GYPP). Zn concentration was correlated negatively with grain yield per plant. On the other hand, no significant relationship was found for grain yield per plant with grain protein content, grain $\mathrm{Fe}, \mathrm{Ca}$ and $\mathrm{Mg}$ content. It was observed that grain $\mathrm{Fe}$ and $\mathrm{Zn}$ as well as grain $\mathrm{Ca}$ and $\mathrm{Mg}$ were positively correlated. ${ }^{*}$ Significant at $P \leq 0.01$; ${ }^{*}$ Significant at $P \leq 0.05$.

In this study too, a hierarchical cluster analysis based on all eight agronomic traits and five grain nutrients over two seasons was performed to group the introgression lines into different clusters. The cluster analysis following Ward's method resulted in 10 clusters (Table S3; Figure 2). Cluster 6 was the largest cluster consisting of 27 ILs followed by cluster 3 ( 21 ILs) and cluster 7 ( 20 ILs). Cluster 2 had only two genotypes, ICPL 85010 and ICPL 20325; both are early maturing cultivars (50\% flowering: 68 days) (Figure 2). All early maturing ILs were grouped into cluster 4 (50\% flowering: 89 days). Cluster 3 had the highest cluster mean for grain yield per plant $(55.12 \mathrm{~g})$ followed by cluster $6(53.33 \mathrm{~g})$ whereas cluster 6 had the highest number of pods per plant (225) followed by cluster 3 (213). Cluster 10 exhibited the lowest means for grain yield per plant ( 21 g) and pod weight per plant ( 32 g) (Table S3). The popular mega variety, ICPL 87119 was grouped into cluster 3 along with the highest yielding introgression line ICPP I71119. Cluster 10 was found to be the best cluster in terms of high Fe content $\left(40 \mathrm{mg} \mathrm{Kg}^{-1}\right)$ but had the lowest grain yield per plant. Also, cluster 4 had highest mean for $\mathrm{Zn}$ content $\left(38 \mathrm{mg} \mathrm{Kg}{ }^{-1}\right.$, "Cluster 2 " has not been considered as it does not hold any ILs) and cluster 8 was found to have ILs with the maximum mean value for grain $\mathrm{Ca}$ $\left(2.15 \mathrm{~g} \mathrm{Kg}^{-1}\right)$ and $\mathrm{Mg}\left(1.48 \mathrm{~g} \mathrm{Kg}^{-1}\right)$ content (Table S3).
The Euclidian distance matrix was estimated to identify the most diverse pair of ILs among the advanced backcross population as well as to identify the most similar and diverse ILs to the popular variety ICPL 87119 and the recurrent parent ICPL 85010 (Table S4). ICPP 171027 was found to be the most diverse (9.09) when compared with ICPL 87119, while ICPP 171031 (2.60) was the most similar IL with ICPL 87119. Likewise, ICPP 171119 was the most diverse (12.42) and ICPP 171033 was the most similar (5.68) accession to the recurrent parent ICPL 85010. Among the 136 ILs, the most diverse pair of accessions were ICPP 171119 and ICPP 171078 with a distance of 10.76 . Top 10 most diverse pairs of accession are given in Table S4; ICPP 171119 was found to be the most diverse IL amongst these top 10 diverse pairs of ILs.

\section{DISCUSSION}

Grain legumes are an excellent and unique source of dietary protein for human beings in many parts of the world. The dietary importance of legumes is expected to increase over the years due to an increased demand for protein and other nutrients by the 
TABLE 3 | Identification of promising trait-specific introgression lines derived from pigeonpea tertiary genepool species C. platycarpus.

\begin{tabular}{|c|c|c|c|c|c|}
\hline Traits & $\begin{array}{c}\text { Number of ILs } \\
\text { significantly } \\
\text { better than ICPL } 87119 \\
\text { (range) }\end{array}$ & ICPL 87119 & $\begin{array}{c}\text { Number of ILs } \\
\text { significantly } \\
\text { better than ICPL } 85010 \\
\text { (range) }\end{array}$ & ICPL 85010 & $\begin{array}{l}\text { Top five performing } \\
\text { ILs against mega cultivar } \\
\text { ICPL } 87119 \\
\text { (range) }\end{array}$ \\
\hline Days to first flowering & $\begin{array}{c}101 \\
(74-110)\end{array}$ & 115 & 0 & 61 & ICPP \#171032, 171030, 171082, 171033, 171027 \\
\hline Days to $50 \%$ flowering & $\begin{array}{c}104 \\
(81-118)\end{array}$ & 123 & 0 & 67 & $\begin{array}{c}\text { ICPP \# 171082, 171032,171027, 171030, } 171024 \\
(81-85)\end{array}$ \\
\hline Plant height (cm) & $\begin{array}{c}50 \\
(138.80-217.36)\end{array}$ & 221.99 & 0 & 110.32 & $\begin{array}{c}\text { ICPP \# 171078, 171073, 171043, 171075, } 171128 \\
(138.80-193.62)\end{array}$ \\
\hline Primary branches (no.) & $\begin{array}{c}1 \\
(26)\end{array}$ & 23 & $\begin{array}{c}93 \\
(16-26)\end{array}$ & 13 & ICPP \# 171022, 171037,171104, 171031, 171098 \\
\hline Secondary branches (no.) & 0 & 15 & $\begin{array}{c}63 \\
(6-14)\end{array}$ & 3 & $\begin{array}{c}\text { ICPP \# 171029, 171094, 171069, 171021, } 171129 \\
(12-14)\end{array}$ \\
\hline Pods per plant (no.) & $\begin{array}{c}53 \\
(189-321)\end{array}$ & 171 & $\begin{array}{c}101 \\
(143-321)\end{array}$ & 126 & $\begin{array}{c}\text { ICPP \# 171006, } 171012,171020,171044,171050 \\
(288-321)\end{array}$ \\
\hline Pod weight per plant (g) & $\begin{array}{c}55 \\
(66.57-123.30)\end{array}$ & 61.38 & $\begin{array}{c}107 \\
(43.64-123.30)\end{array}$ & 38.21 & $\begin{array}{c}\text { ICPP \# 171119, 171012, 171006, 171088, } 171020 \\
(103.66-123.30)\end{array}$ \\
\hline Grain yield per plant (g) & $\begin{array}{c}28 \\
(51.99-82.87)\end{array}$ & 48.18 & $\begin{array}{c}111 \\
(29.44-82.87)\end{array}$ & 24.72 & $\begin{array}{c}\text { ICPP \# 171119, 171012, 171020, 171088, } 171029 \\
(68.19-82.87)\end{array}$ \\
\hline Protein (\%) & $\begin{array}{c}136 \\
(19.33-23.01)\end{array}$ & 18.88 & $\begin{array}{c}54 \\
(21.10-23.01)\end{array}$ & 20.79 & $\begin{array}{c}\text { ICPP \# 171053, 171014, 171039, 171132, } 171115 \\
(22.51-23.01)\end{array}$ \\
\hline $\mathrm{Fe}\left(\mathrm{mg} \mathrm{kg}^{-1}\right)$ & $\begin{array}{c}104 \\
(33.60-42.50)\end{array}$ & 31.75 & $\begin{array}{c}80 \\
(35.23-42.50)\end{array}$ & 33.36 & $\begin{array}{c}\text { ICPP \# 171078, 171077, 171009,171090, } 171076 \\
(41.07-42.50)\end{array}$ \\
\hline $\mathrm{Zn}\left(\mathrm{mg} \mathrm{kg}^{-1}\right)$ & $\begin{array}{c}102 \\
(32.12-41.76)\end{array}$ & 29.33 & 0 & 40.56 & $\begin{array}{c}\text { ICPP \# 171027, } 171082,171032,171132,171023 \\
(39.42-41.76)\end{array}$ \\
\hline $\mathrm{Ca}\left(\mathrm{g} \mathrm{kg}^{-1}\right)$ & $\begin{array}{c}74 \\
(1.35-3.09)\end{array}$ & 1.20 & $\begin{array}{c}88 \\
(1.26-3.09)\end{array}$ & 1.11 & $\begin{array}{c}\text { ICPP \# 171010, 171045, 171127, } 171104,171077 \\
(2.28-3.09)\end{array}$ \\
\hline $\operatorname{Mg}\left(g_{~ k g}{ }^{-1}\right)$ & $\begin{array}{c}45 \\
(1.35-1.59)\end{array}$ & 1.27 & $\begin{array}{c}115 \\
(1.22-1.59)\end{array}$ & 1.14 & $\begin{array}{c}\text { ICPP \# 171077, } 171014,171022,171051,171127 \\
(1.53-1.59)\end{array}$ \\
\hline
\end{tabular}

TABLE 4 | Performance of 28 promising high-yielding introgression lines for important agronomic traits and grain nutrients.

\begin{tabular}{|c|c|c|c|c|c|c|c|c|c|}
\hline Geno & DF50\# & PPP & PWPP & GYPP & Protein & $\mathrm{Fe}$ & $\mathrm{Zn}$ & $\mathrm{Ca}$ & $\mathbf{M g}$ \\
\hline ICPP 171119 & 131 & $285^{\star}$ & $123.30^{*}$ & $82.87^{\star}$ & $20.78^{\star}$ & 29.82 & $30.35^{\dagger}$ & 0.93 & 1.19 \\
\hline ICPP 171012 & $109^{\star}$ & $301^{*}$ & $108.45^{\star}$ & $73.36^{\star}$ & $20.86^{\star}$ & $35.36^{\star}$ & $36.16^{\star}$ & $1.39^{\star}$ & $1.30^{\dagger}$ \\
\hline ICPP 171020 & $119^{\dagger}$ & $294^{*}$ & $103.66^{*}$ & $70.31^{\star}$ & $19.60^{\star}$ & $33.88^{\star}$ & $31.17^{\dagger}$ & $1.20^{\dagger}$ & $1.30^{\dagger}$ \\
\hline ICPP 171088 & 127 & $260^{\star}$ & $103.98^{\star}$ & $69.96^{\star}$ & $19.80^{\star}$ & $33.82^{\star}$ & 27.61 & $1.20^{\dagger}$ & 1.23 \\
\hline ICPP 171029 & $121^{\dagger}$ & $207^{*}$ & $97.43^{\star}$ & $68.19^{\star}$ & $21.32^{\star}$ & $38.41^{*}$ & $32.97^{\star}$ & $1.29^{\dagger}$ & $1.35^{\star}$ \\
\hline ICPP 171044 & 130 & $292^{*}$ & $101.16^{*}$ & $66.02^{*}$ & $21.81^{\star}$ & $36.05^{*}$ & $33.44^{\star}$ & $1.98^{\star}$ & $1.39^{*}$ \\
\hline ICPP 171004 & $111^{*}$ & $248^{*}$ & $94.39^{\star}$ & $64.58^{\star}$ & $20.09^{\star}$ & $33.89^{*}$ & $31.53^{\dagger}$ & $1.46^{\star}$ & $1.29^{\dagger}$ \\
\hline ICPP 171102 & $116^{\star}$ & $271^{*}$ & $90.16^{\star}$ & $63.19^{\star}$ & $20.91^{\star}$ & $33.97^{\star}$ & $31.40^{\dagger}$ & 1.25 & $1.42^{*}$ \\
\hline ICPP 171129 & $117^{\star}$ & $194^{*}$ & $88.80^{\star}$ & $63.11^{*}$ & $21.11^{\star}$ & $34.57^{*}$ & $31.52^{\dagger}$ & 1.08 & 1.23 \\
\hline ICPP 171087 & $110^{*}$ & $196^{\star}$ & $86.07^{\star}$ & $62.50^{\star}$ & $20.27^{\star}$ & 26.35 & $29.73^{\dagger}$ & $2.06^{\star}$ & $1.41^{*}$ \\
\hline ICPP 171006 & $109^{*}$ & $321^{*}$ & $107.96^{*}$ & $62.20^{\star}$ & $21.31^{\star}$ & $38.90^{*}$ & $36.09^{*}$ & $1.60^{\star}$ & $1.41^{*}$ \\
\hline ICPP 171050 & $116^{\star}$ & $288^{*}$ & $96.41^{\star}$ & $61.91^{*}$ & $20.86^{\star}$ & $36.28^{\star}$ & $31.51^{\dagger}$ & $1.90^{\star}$ & $1.31^{\dagger}$ \\
\hline ICPP 171098 & 124 & $206^{*}$ & $89.29^{\star}$ & $61.57^{\star}$ & $19.72^{\star}$ & $38.45^{\star}$ & $29.49^{\dagger}$ & $1.27^{\dagger}$ & $1.36^{\star}$ \\
\hline ICPP 171094 & $115^{\star}$ & $223^{*}$ & $89.36^{\star}$ & $60.21^{*}$ & $21.35^{\star}$ & $39.50^{*}$ & $36.60^{\star}$ & $1.49^{\star}$ & $1.33^{\dagger}$ \\
\hline ICPP 171021 & $112^{\star}$ & $202^{*}$ & $87.82^{\star}$ & $59.12^{\star}$ & $20.89^{\star}$ & $32.01^{\dagger}$ & $32.47^{\star}$ & $1.43^{\star}$ & $1.31^{\dagger}$ \\
\hline ICPP 171025 & $118^{*}$ & $218^{*}$ & $84.29^{\star}$ & $58.88^{\star}$ & $21.63^{\star}$ & $37.59^{\star}$ & $36.71^{*}$ & $2.05^{\star}$ & $1.45^{\star}$ \\
\hline ICPP 171001 & $110^{\star}$ & $215^{\star}$ & $81.37^{\star}$ & $58.82^{*}$ & $20.05^{\star}$ & $36.93^{*}$ & $36.01^{\star}$ & 1.01 & $1.37^{\star}$ \\
\hline ICPP 171085 & $112^{\star}$ & $199^{*}$ & $89.20^{\star}$ & $58.70^{\star}$ & $22.16^{\star}$ & $38.21^{*}$ & $36.06^{\star}$ & $1.52^{*}$ & $1.47^{*}$ \\
\hline ICPP 171048 & $114^{*}$ & $273^{*}$ & $89.13^{\star}$ & $57.53^{\star}$ & $21.10^{\star}$ & $37.40^{*}$ & $34.41^{\star}$ & $1.77^{\star}$ & 1.23 \\
\hline ICPP 171045 & 129 & $278^{*}$ & $89.86^{\star}$ & $57.31^{*}$ & $20.60^{*}$ & $34.81^{*}$ & $31.38^{\dagger}$ & $2.61^{*}$ & $1.47^{*}$ \\
\hline ICPP 171131 & $109^{*}$ & $231^{*}$ & $75.77^{\star}$ & $56.51^{*}$ & $20.95^{\star}$ & 29.98 & $32.03^{\dagger}$ & 1.05 & 1.07 \\
\hline ICPP 171059 & $112^{\star}$ & $202^{*}$ & $84.29^{\star}$ & $55.83^{\star}$ & $20.79^{\star}$ & 31.06 & $34.03^{\star}$ & 1.02 & $1.32^{\dagger}$ \\
\hline ICPP 171097 & $110^{\star}$ & $195^{\star}$ & $81.31^{\star}$ & $55.77^{\star}$ & $20.08^{\star}$ & $37.13^{\star}$ & $35.46^{\star}$ & $1.27^{\dagger}$ & $1.34^{\dagger}$ \\
\hline ICPP 171046 & $120^{\dagger}$ & $247^{*}$ & $77.58^{\star}$ & $53.90^{\star}$ & $21.19^{\star}$ & $39.00^{*}$ & $32.92^{\star}$ & $1.60^{\star}$ & 1.19 \\
\hline ICPP 171127 & $117^{\star}$ & $216^{\star}$ & $77.53^{\star}$ & $53.13^{*}$ & $21.51^{\star}$ & $35.26^{*}$ & $30.09^{\dagger}$ & $2.39^{\star}$ & $1.53^{*}$ \\
\hline ICPP 171113 & 128 & $181^{\dagger}$ & $81.11^{*}$ & $53.03^{\star}$ & $20.21^{\star}$ & $40.05^{\star}$ & $33.77^{\star}$ & $1.54^{\star}$ & $1.31^{\dagger}$ \\
\hline ICPP 171003 & $114^{\star}$ & $213^{*}$ & $75.03^{\star}$ & $52.54^{\star}$ & $19.50^{\star}$ & $35.92^{*}$ & $35.95^{\star}$ & $1.23^{\dagger}$ & $1.31^{\dagger}$ \\
\hline ICPP 171011 & $117^{\star}$ & $204^{*}$ & $76.95^{\star}$ & $51.99^{*}$ & $20.77^{\star}$ & $34.25^{\star}$ & $33.71^{\star}$ & $1.63^{\star}$ & $1.42^{\star}$ \\
\hline ICPL 87119 & 123 & 171 & 61.38 & 48.18 & 18.88 & 31.75 & 29.33 & 1.20 & 1.27 \\
\hline
\end{tabular}

"DF50, Day to 50\% flowering; PPP, Number of pods per plant; PWPP, pod weight per plant; GYPP, Grain yield per plant. *Significantly better than popular variety ICPL 87119 (Asha) at P $0.05{ }^{\dagger}$ Better than ICPL 87119 on per se basis. 


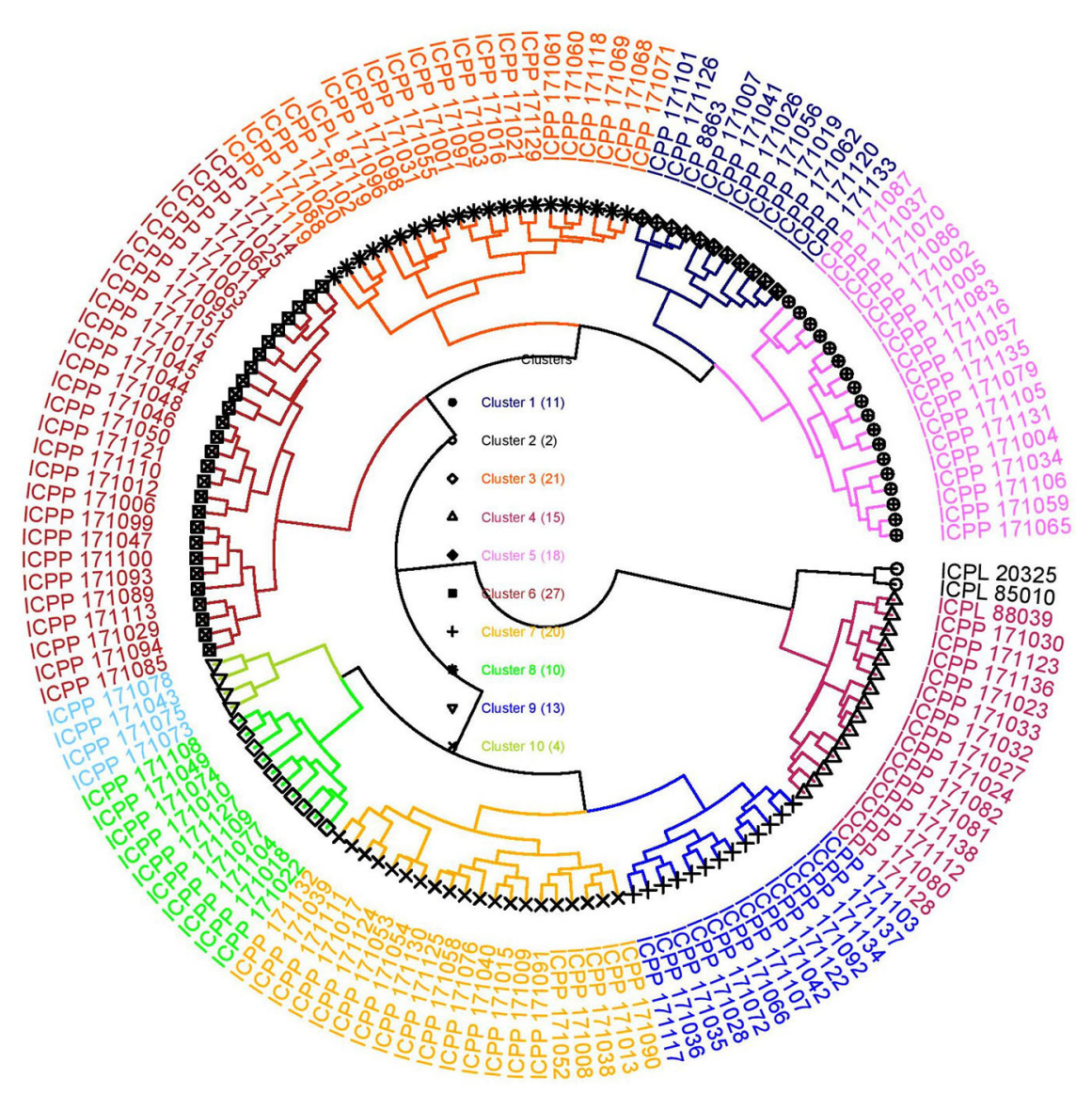

FIGURE 2 | Cluster diagram depicting different clusters formed using 136 introgression lines derived from C. platycarpus and five popular varieties following Ward's method based on agronomic and grain nutrient traits. The "Cluster 2 " consisted of only two lines: the recurrent parent ICPL 85010 along with another popular variety ICPL 20325. The highest yielding introgression line ICPP 171119 grouped in "Cluster 3" along with mega variety ICPL 87119.

growing world population (Duranti, 2006). Moreover, the development of climate-resilient, nutrient-rich crop varieties is expected to reduce the number of malnourished people worldwide, especially in South Asia and Sub-Saharan Africa (Varshney et al., 2019). The crop varieties with improved nutrition may also be useful in addressing the UN Millennium goal of zero hunger and malnutrition, particularly in those parts of the world where plant-based protein is in high demand.

Pigeonpea is an excellent protein-rich legume crop that is mainly grown under rainfed conditions on marginal lands with minimal inputs and plays an important role in subsistence agriculture (Bohra et al., 2017; Obala et al., 2018). The modern pigeonpea cultivars have a narrow genetic base due to the frequent use of a few promising lines in the hybridization programs over the years. (Kumar et al., 2004; Bohra et al., 2010; Sharma et al., 2019). To meet the growing demand for plant-based nutrition and the need for soil health rejuvenation by implementing a proper cropping system, the pigeonpea breeding programs must embrace a few novel approaches (Anitha et al., 2019). The high-yielding nutrient-rich varieties will attract farmers not only in developing countries where the crop is being cultivated traditionally but will also find a niche in new environments in the developed countries (Atlin et al., 2017). Crop wild relatives (CWRs) are an excellent source of new alleles for different useful traits required for pigeonpea improvement (Khoury et al., 2015; Sharma and Upadhyaya, 2016; Sharma et al., 2019). But due to many hindrances such as cross incompatibility, late maturity, undesirable pod traits, poor agronomic performance, high photoperiod sensitivity, etc., breeders are disinclined to use these CWRs in crop improvement programs (Sharma et al., 2013). In this context, pre-breeding plays a vital role to enhance the use of wild relatives in breeding programs by providing the ready-to-use ILs with superior alleles for different traits introgressed from wild species.

The pre-breeding population consisting of 136 ILs used in the present study was derived from a cross-incompatible tertiary genepool species, C. platycarpus following embryo rescue technique (Mallikarjuna et al., 2011) with a view to introgress important traits such as early maturity, high protein content, and photoperiod insensitivity into cultivated pigeonpea. A large genetic variation was observed for important agronomic traits such as days to $50 \%$ flowering, number of pods per plant, grain yield as well as for the grain nutrients viz., protein, grain Fe, $\mathrm{Zn}$, $\mathrm{Ca}$, and $\mathrm{Mg}$ content. The genetic variation found in this 
backcross population is expected to be noble with broad genetic bases as it is derived from wild species.

Based on the days to maturity (duration from planting to $75 \%$ maturity), pigeonpea cultivars/varieties are grouped into different groups such as super-early (50-60 days to flowering and/or $<100$ days to maturity), extra-early (60-80 days to flowering and/or 101-120 days to maturity), early (81-100 days to flowering and/or 121-140 days to maturity), mid-early (101-120 days to flowering and/or 141-160 days to maturity), medium (111-130 days to flowering and/or 161-180 days to maturity) and late (>130days to flowering and/or $>180$ days to maturity) maturity duration groups (Srivastava et al., 2012). In general, major pigeonpea cultivation is dominated by varieties in the medium-maturity group (Choudhary and Nadarajan, 2011). Under changing climatic conditions, there is an emphasis on developing short-duration pigeonpea cultivars having photo- and thermo-insensitivity to fit into multiple cropping systems as well as to expand pigeonpea cultivation into new niche areas (Saxena et al., 2019).

Though short duration lines are available, there is a huge yield penalty compared to popular medium-maturing varieties such as ICPL 87119. Most of the high-yielding ILs identified in the present study flowered early and had significantly higher yield and better grain nutrient contents than all the control cultivars used in this study including popular variety, ICPL 87119. The most promising high-yielding ILs such as ICPP \# 171012, $171004,171102,171087,171006$, and 171050 having early flowering, high yield, and better grain nutrient contents hold great potential for ready use in pigeonpea breeding programs.

Dwarf plant type is not an advantageous feature for pigeonpea as it attracts Helicoverpa armigera and the dwarf bushy growth habit lines have shown $40 \%$ damage due to $H$. armigera (Mallikarjuna et al., 2011). Interestingly, all the ILs in this study were tall with semi-spreading secondary and tertiary branches and indeterminate growth habit. Plant height in pigeonpea is a complex and quantitative trait (Byth et al., 1981). The ILs evaluated were found taller than their recurrent parent ICPL 85010 and were similar to ICPL 87119 which puts the ILs in an advantageous position. Also, the range of yieldcontributing traits such as number of pods per plant, pod weight per plant, and grain yield per plant was very high indicating the high level of recombination in these ILs.

Grain nutrients were found to be highly influenced by genotype and genotype $\times$ environment interactions. The stability of these traits in different environments is therefore important in crop improvement programs to improve the nutritional quality of pigeonpea. Non-significant correlations were observed between grain yield and grain nutrients except grain $\mathrm{Zn}$ content. This indicates the possibility to develop nutrient-rich pigeonpea varieties without the trade-offs for yield. Besides, a positive association was observed between the grain nutrients, such as of protein with all four grain nutrients suggesting the simultaneous improvement of varieties with enhanced multiple nutrient contents. Grain Fe and Zn content also showed a significant correlation which is reported in several crops including wheat (Morgounov et al., 2007), sorghum (Upadhyaya et al., 2016; Phuke et al., 2017), pearl millet (Kanatti et al., 2014), proso millet (Vetriventhan and Upadhyaya, 2018), and finger millet (Upadhyaya et al., 2011).

Further, it is important to study the similarity/dissimilarity of ILs with control cultivars for use in breeding programs. The cluster analysis grouped 136 ILs with 5 control cultivars into 10 clusters wherein similar ILs were placed in the same cluster based on agronomic traits and grain nutrients. This will help the breeders to choose trait-specific and diverse ILs for use in a breeding program to introduce new useful alleles derived from wild species into their working collection and/or newly developed cultivars/varieties. In addition, the most diverse pairs of ILs have been identified based on the mean phenotypic diversity index. Involving most diverse ILs in hybridization programs would be helpful in generating new and useful recombinants. Apart from this, a few ILs such as ICPP 171119, ICPP 171098, and ICPP 171045 showing maximum diversity with the recurrent parent ICPL 85010; and ICPP 171027, ICPP 171082, and ICPP 171024 having maximum diversity with the popular variety, ICPL 87119 have been identified for use in breeding programs to develop new cultivars with a broad genetic base.

\section{CONCLUSION}

Significant variability was observed in the pre-breeding population, derived from the cross incompatible tertiary genepool species, $C$. platycarpus, for agronomic traits and grain nutrients. Moreover, it is noteworthy that many ILs performed better than the existing mega varieties not only in terms of yield but also for nutrient contents. The most promising high-yielding ILs such as ICPP \# 171012, 171004, $171102,171087,171006$, and 171050 having early flowering, high yield, and better grain nutrient contents compared to the best variety, ICPL 87119 hold great potential for ready use in pigeonpea breeding programs. A thorough multi-location evaluation of these promising trait-specific ILs will be efficacious in identifying regionspecific promising lines for their possible direct release as a cultivar (s) having a diverse genetic base, especially in the short-duration group to fit into multiple cropping systems. Further, as no correlations were observed between grain yield and grain nutrients, it shows the possibility of developing nutrient-rich pigeonpea varieties without the trade-offs for yield. Positive associations of grain protein with all four grain nutrients suggests the simultaneous improvement of varieties with enhanced multiple nutrient contents. Besides this, the most diverse promising ILs can be included in the hybridization programs as the potential sources of new and diverse variations. Finally, as C. platycarpus is reported to possess photoperiod insensitivity, these ILs hold great potential for evaluation across locations and seasons to identify photoinsensitive lines for use in breeding programs.

\section{DATA AVAILABILITY STATEMENT}

All datasets generated for this study are included in the article/ Supplementary Material. 


\section{AUTHOR CONTRIBUTIONS}

SS conceived the idea and evaluated the material. CS was involved in field evaluation. PP analyzed the data and assisted in preparing the first draft. $\mathrm{CN}$ analyzed the seed samples for grain nutrient contents in quality lab. SS prepared the final manuscript. CS, PP, and CN provided their inputs. All authors contributed to the article and approved the submitted version.

\section{FUNDING}

Funding support provided by the Global Crop Diversity Trust (GCDT) Grant Numbers GS15020 and GS18010 and CGIAR Research Program on Grain Legumes and Dryland Cereals (GLDC).

\section{REFERENCES}

Anitha, S., Govindaraj, M., and Kane- Potaka, J. (2019). Balanced amino acid and higher micronutrients in millets complements legumes for improved human dietary nutrition. Cereal Chem. 97, 74-84. doi: 10.1002/cche.10227

Ariyanayagam, R. P., and Spence, J. A. (1978). A possible gene source for early, day-length neutral pigeon peas, Cajanus cajan (L.) Millsp. Euphytica 27, 505509. doi: $10.1007 /$ bf00043176

Atlin, G. N., Cairns, J. E., and Das, B. (2017). Rapid breeding and varietal replacement are critical to adaptation of cropping systems in the developing world to climate change. Global Food Secur. 12, 31-37. doi: 10.1016/ j.gfs.2017.01.008

Bohra, A., Mallikarjuna, N., Saxena, K. B., Upadhyaya, H. D., Vales, I., and Varshney, R. K. (2010). Harnessing the potential of crop wild relatives through genomics tools for pigeonpea improvement. J. Plant Biol. 37, 83-98.

Bohra, A., Pareek, S., Jha, R., Saxena, R. K., Singh, I. P., Pandey, G., et al. (2017). "Modern genomic tools for pigeonpea improvement: status and prospects," in The Pigeonpea Genome. Eds. R. K. Varshney, R. K. Saxena and S. A. Jackson (Cham: Springer International Publishing), 41-54. doi: 10.1007/978-3-31963797-6_5

Byth, D. E., Wallis, E. S., and Saxena, K. B. (1981). “Adaptation and breeding strategies for Pigeonpea," in Proceedings of the International Workshop on Pigeonpeas. vol. 1. (India: ICRISAT), 450-465.

Choudhary, A. K., and Nadarajan, N. (2011). Breeding improved cultivars of pigeonpea in India (Kanpur, India: Research Bulletin. Indian Pulses Research Institute).

Dahiya, S. S., Chauhan, Y. S., Srinvastava, S. K., Sekhon, H. S., Waldia, R. S., Gowda, C. L. L., et al. (2001). Growing extra-short duration pigeonpea in rotation with wheat in the Indo-Gangetic Plain. No. 1. 2001. Report (Hyderabad, India: ICRISAT).

Dundas, I. S. (1990). "Pigeonpea: cytology and cytogenetics-perspectives and prospects," in The Pigeonpea. Eds. Y. L. Nene, S. D. Hall and V. K. Sheila (Wallington, UK: CABI Publ), 117-136.

Duranti, M. (2006). Grain legume proteins and nutraceutical properties. Fitoterapia 77, 67-82. doi: 10.1016/j.fitote.2005.11.008

FAOSTAT (2017). Food and Agriculture Organization of the United Nations Database. (Rome, Italy: Food and Agriculture Organization). Available at: http://faostat.fao.org/database.

IBPGR and ICRISAT (1993). Descriptors for pigeonpea [Cajanus cajan (L.) Millsp.] (Rome, Italy: IBPGR and Patancheru, India: ICRISAT), 31.

ICARDA (1995). Annual report for 1995 (ICARDA, Aleppo, Syria: Germplasm Program Legumes).

Kanatti, A., Rai, K. N., Radhika, K., Govindaraj, M., Sahrawat, K. L., and Rao, A. S. (2014). Grain iron and zinc density in pearl millet: combining ability, heterosis and association with grain yield and grain size. SpringerPlus 3, 763. doi: $10.1186 / 2193-1801-3-763$

\section{ACKNOWLEDGMENTS}

This work is part of the initiative "Adapting Agriculture to Climate Change: Collecting, Protecting and Preparing Crop Wild Relatives" which is supported by the Government of Norway. The project is managed by the Global Crop Diversity Trust. For further information, visit the project website: http:// www.cwrdiversity.org/. The partial funding support provided by the CGIAR Research Program on Grain Legumes and Dryland Cereals (GLDC) is duly acknowledged.

\section{SUPPLEMENTARY MATERIAL}

The Supplementary Material for this article can be found online at: https://www.frontiersin.org/articles/10.3389/fpls.2020.01055/ full\#supplementary-material

Khoury, C. K., Castañeda-Alvarez, N. P., Achicanoy, H. A., Sosa, C. C., Bernau, V., Kassa, M. T., et al. (2015). Crop wild relatives of pigeonpea [Cajanus cajan (L.) Millsp.]: Distributions, ex situ conservation status, and potential genetic resources for abiotic stress tolerance. Biol. Cons. 184, 259-270. doi: 10.1016/ j.biocon.2015.01.032

Knights, E. J., Southwell, R. J., Schwinghamer, M. W., and Harden, S. (2008). Resistance to Phytophthora medicaginis Hansen and Maxwell in wild Cicer species and its use in breeding root rot resistant chickpea (Cicer arietinum L.). J. Agric. Res. 59383-, 387. doi: 10.1071/AR07175

Kumar, S., Gupta, S., Chandra, S., and Singh, B. B. (2004). "How wide is genetic base of pulse crops?" in Pulses in new perspective," in Proceedings of the National Symposium on Crop Diversification and Natural Resources Management. Eds. M. Ali, B. B. Singh, S. Kumar and V. Dhar (Kanpur: Indian Society of Pulses Research and Development, Indian Institute of Pulses Research), 211-221.

Lava Kumar, P., Latha, T. K. S., Kulkarni, N. K., Raghavendra, N., Saxena, K. B., Waliyar, F., et al. (2005). Broad-based resistance to pigeonpea sterility mosaic disease in wild relatives of pigeonpea (Cajanus: Phaseoleae). Ann. Appl. Biol. 146, 371-379. doi: 10.1111/j.1744-7348.2005.040091.x

Malhotra, R. S., Singh, K. B., Vito, M., Greco, N., and Saxena, M. C. (2002). Registration of ILC 10765 and ILC 10766 chickpea germplasm lines resistant to cyst nematode. Crop Sci. 42, 1756. doi: 10.2135/cropsci2002.1756

Mallikarjuna, N., and Moss, J. P. (1995). Production of hybrids between Cajanus platycarpus and Cajanus cajan. Euphytica 83, 43-46. doi: 10.1007/BF01677859

Mallikarjuna, N., Jadhav, D., and Reddy, P. (2006). Introgression of Cajanus platycarpus genome into cultivated pigeonpea, C. cajan. Euphytica 149, 161167. doi: 10.1007/s10681-005-9063-6

Mallikarjuna, N., Senthilvel, S., Jadhav, D. R., Saxena, K. B., Sharma, H. C., Upadhyaya, H. D., et al. (2011). Progress in the utilization of Cajanus platycarpus (Benth.) Maesen in pigeonpea improvement. Plant Breed. 130, 507-514. doi: 10.1111/j.1439-0523.2011.01870.x

Morgounov, A., Gómez-Becerra, H. F., Abugalieva, A., Dzhunusova, M., Yessimbekova, M., Muminjanov, H., et al. (2007). Iron and zinc grain density in common wheat grown in Central Asia. Euphytica 155, 193-203. doi: 10.1007/s10681-006-9321-2

Obala, J., Saxena, R. K., Singh, V. K., Vechalapu, S., Das, R. R., Rathore, A., et al. (2018). Genetic variation and relationships of total seed protein content with some agronomic traits in pigeonpea (Cajanus cajan (L.) Millsp.). Aust. J. Crop Sci. 12, 1859-1865. doi: 10.21475/ajcs.18.12.12.p1138

Patterson, H. D., and Thompson, R. (1971). Recovery of inter-block information when block sizes are unequal. Biometrika 58, 545-554. doi: 10.2307/2334389

Phuke, R. M., Anuradha, K., Radhika, K., Jabeen, F., Anuradha, G., Ramesh, T., et al. (2017). Genetic variability, genotype $\times$ environment interaction, correlation, and GGE biplot analysis for grain iron and zinc concentration and other agronomic traits in RIL population of sorghum (Sorghum bicolor $\mathrm{L}$. Moench). Front. Plant Sci. 8, 712. doi: 10.3389/fpls.2017.00712 
Pundir, R. P. S., and Singh, R. B. (1987). Possibility of genetic improvement of pigeonpea (Cajanus cajan (L.) Millsp.) utilizing wild gene sources. Euphytica 36, 33-37. doi: 10.1007/bf00730644

Rao, N. K., Reddy, L. J., and Bramel, P. J. (2003). Potential of wild species for genetic enhancement of some semi-arid food crops. Genet. Resour. Crop Ev. 50, 707-721. doi: 10.1023/A:1025055018954

Sahrawat, K. L., Kumar, G. R., and Murthy, K. V. S. (2002). Sulfuric acid-selenium digestion for multi-element analysis in a single plant digest. Commun. Soil Sci. Plant Anal. 33, 3757-3765. doi: 10.1081/css-120015920

Saxena, K. B., Singh, L., Reddy, M. V., Singh, U., Lateef, S. S., Sharma, S. B., et al. (1990). Intra species variation in Atylosia scarabaeoides (L.) Benth., a wild relative of pigeonpea (Cajanus cajan (L.) Millsp.). Euphytica 49, 185-191. doi: 10.1007/BF00036287

Saxena, K. B., Rao, A. N., Singh, U., and Remanandan, P. (1996). Intraspecies variation in Cajanus platycarpus for some agronomic traits and crossability. Int. Chickpea Pigeonpea Newslett. 3, 49-51.

Saxena, K. B., Kumar, R. V., and Sultana, R. (2010). Quality nutrition through pigeonpea-a review. Health 02, 1335-1344. doi: 10.4236/health.2010.211199

Saxena, K., Choudhary, A. K., Srivastava, R. K., Bohra, A., Saxena, R. K., and Varshney, R. K. (2019). Origin of early maturing pigeonpea germplasm and its impact on adaptation and cropping systems. Plant Breed 138, 243-251. doi: $10.1111 /$ pbr.12696

Sharma, S., and Upadhyaya, H. D. (2016). Interspecific hybridization to introduce useful genetic variability for pigeonpea improvement. Indian J. Genet. Pl. Br. 76, 496-503. doi: 10.5958/0975-6906.2016.00067.5

Sharma, S. B., Remanandan, P., and McDonald, D. (1993). Resistance to Meloidogyne javanica and Rotylenchulus reniformis in wild relatives of pigeonpea. J. Nematol. 25, 824-829.

Sharma, S., Upadhyaya, H. D., Varshney, R. K., and Gowda, C. L. L. (2013). Prebreeding for diversifcation of primary genepool and genetic enhancement of grain legumes. Front. Plant Sci. 4, 309. doi: 10.3389/fpls.2013.00309

Sharma, S., Paul, P. J., Kumar, C. V., Rao, P. J., Prasanthi, L., Muniswamy, S., et al. (2019). Evaluation and identification of promising introgression lines derived from wild Cajanus species for broadening the genetic base of cultivated pigeonpea (Cajanus cajan (L.) Millsp.). Front. Plant Sci. 10, 1269. doi: 10.3389/fpls.2019.01269

Sharma, S. B. (1995). Resistance to Rotylenchulus reniformis, Heterodera cajani, and Meloidogyne javanica in accessions of Cajanus platycarpus. Plant Dis. 79, 1033-1035. doi: 10.1094/PD-79-1033

Singh, S., Gumber, R. K., Joshi, N., and Singh, K. (2005). Introgression from wild Cicer reticulatum to cultivated chickpea for productivity and disease resistance. Plant Breed. 124477-, 480. doi: 10.1111/j.1439-0523.2005.01146.x

Srivastava, R. K., Vales, M. I., Sultana, R., Saxena, K. B., Kumar, R. V., Tanki, H. P., et al. (2012). Development of 'super-early' pigeonpeas with good yield potential from early $\times$ early crosses. J. SAT Agric. Res. 10, 1-6.
Subbarao, G. V. (1988). Salinity tolerance in pigeonpea (Cajanus cajan) and its wild relatives. [Ph.D. dissertation] (Kharagpur, India: Indian Institute of Technology).

Sujana, G., Sharma, H. C., and Manohar, R. D. (2008). Antixenosis and antibiosis components of resistance to pod borer, Helicoverpa armigera in wild relatives of pigeonpea. Int. J. Trop. Insect Sci. 28, 191-200. doi: 10.1017/ S1742758408191822

Upadhyaya, H. D., Ramesh, S., Sharma, S., Singh, S. K., Varshney, S. K., Sarmad, N. D. R. K., et al. (2011). Genetic diversity for grain nutrient contents in a core collection of finger millet (Eleusine coracana (L.) Gaertn.) germplasm. Field Crops Res. 121, 42-52. doi: 10.1016/ j.fcr.2010.11.017

Upadhyaya, H. D., Dwivedi, S. L., Singh, S., Sahrawat, K. L., and Singh, S. K. (2016). Genetic variation and post flowering drought effects on seed iron and zinc in ICRISAT sorghum mini core collection. Crop Sci. 56, 374. doi: 10.2135/ cropsci2015.05.0308

Varshney, R. K., Thudi, M., Roorkiwal, M., He, W., Upadhyaya, H. D., Yang, W., et al. (2019). Resequencing of 429 chickpea accessions from 45 countries provides insights into genome diversity, domestication and agronomic traits. Nat. Genet. 51, 857-864. doi: 10.1038/s41588-019-0401-3

Vetriventhan, M., and Upadhyaya, H. D. (2018). Diversity and trait-specific sources for productivity and nutritional traits in the global proso millet (Panicum miliaceum L.) germplasm collection. Crop J. 6, 451-463. doi: 10.1016/j.cj.2018.04.002

Ward, J. H. (1963). Hierarchical Grouping to Optimize an Objective Function. J. Am. Stat. Assoc. 58, 236-244. doi: 10.1080/01621459.1963.10500845

Wheal, M. S., Fowles, T. O., and Palmer, L. T. (2011). A cost-effective acid digestion method using closed polypropylene tubes for inductively coupled plasma optical emission spectrometry (ICP-OES) analysis of plant essential elements. Anal. Methods 3, 2854-2863. doi: 10.1039/c1ay05430a

Conflict of Interest: The authors declare that the research was conducted in the absence of any commercial or financial relationships that could be construed as a potential conflict of interest.

The reviewer PK declared a past co-authorship with one of the authors SS to the handling editor.

Copyright (C) 2020 Sharma, Paul, Sameer Kumar and Nimje. This is an open-access article distributed under the terms of the Creative Commons Attribution License (CC $B Y$ ). The use, distribution or reproduction in other forums is permitted, provided the original author(s) and the copyright owner(s) are credited and that the original publication in this journal is cited, in accordance with accepted academic practice. No use, distribution or reproduction is permitted which does not comply with these terms. 